SUBJECT AREAS: BIOGEOCHEMISTRY

GEOCHEMISTRY

Received

30 December 2013

Accepted

31 March 2014

Published

16 April 2014

Correspondence and requests for materials should be addressed to

Z.L.S.

(songzhaoliang78@ 163.com)

\section{Phylogenetic variation of phytolith carbon sequestration in bamboos}

\author{
Beilei Li' , Zhaoliang Song ${ }^{1,2}$, Zimin Li ${ }^{1,3}$, Hailong Wang ${ }^{1}$, Renyi Gui ${ }^{4} \&$ Ruisheng Song ${ }^{4}$
}

'School of Environment and Resources, Zhejiang Agricultural and Forestry University, Lin'an, Zhejiang 311300 , China, ${ }^{2}$ State Key Laboratory of Environmental Geochemistry, Institute of Geochemistry, Chinese Academy of Sciences, Guizhou, P.R. China, ${ }^{3}$ Tea Research Institute of Chinese Academy of Agricultural Sciences and the Key Laboratory for Plant Biology and Resource Application of Tea, the Ministry of Agriculture, China, $310008,{ }^{4}$ School of Forestry and Bio-technology, Zhejiang Agricultural and Forestry University, Lin'an, Zhejiang 311300 , China.

Phytoliths, the amorphous silica deposited in plant tissues, can occlude organic carbon (phytolith-occluded carbon, PhytOC) during their formation and play a significant role in the global carbon balance. This study explored phylogenetic variation of phytolith carbon sequestration in bamboos. The phytolith content in bamboo varied substantially from $4.28 \%$ to $16.42 \%$, with the highest content in Sasa and the lowest in Chimonobambusa, Indocalamus and Acidosasa. The mean PhytOC production flux and rate in China's bamboo forests were $62.83 \mathrm{~kg} \mathrm{CO}_{2} \mathrm{ha}^{-1} \mathrm{y}^{-1}$ and $4.5 \times 10^{8} \mathrm{~kg} \mathrm{CO}_{2} \mathrm{y}^{-1}$, respectively. This implies that $1.4 \times$ $10^{9} \mathrm{~kg} \mathrm{CO}_{2}$ would be sequestered in world's bamboo phytoliths because the global bamboo distribution area is about three to four times higher than China's bamboo. Therefore, both increasing the bamboo area and selecting high phytolith-content bamboo species would increase the sequestration of atmospheric $\mathrm{CO}_{2}$ within bamboo phytoliths.

P

hytoliths are the amorphous silica deposited in plant tissues such as the cell wall, cell lumen and intercellular space during plant growth ${ }^{1-3}$. They are present in many plants, especially abundant in gramineous plants, e.g., bamboo ${ }^{4-5}$. A large amount of phytoliths are released in the topsoil through plant organic matter decomposition ${ }^{6-7}$. Importantly, phytoliths are very stable in some sediments ${ }^{8}$ or even in harsh environments such as flood, earthquake and dust storms $s^{9-11}$, due to their strong resistance to degradation ${ }^{6,11,12}$. Recent researches report that during the formation of phytoliths, $1 \%-6 \%$ organic carbon can be sequestered within the phytoliths, also called phytolith-occluded carbon (PhytOC $)^{6,13}$, which plays an important role in the global carbon cycle and climate change as a "safe" carbon sink $\mathrm{k}^{14,1}$.

Bamboo, a typical phytolith-accumulator ${ }^{5,16}$, is predominantly distributed in the world tropical and subtropical regions, with a total area of $2.2 \times 10^{7} \mathrm{ha}^{17}$, occupying about $1 \%$ of the total global forest distribution area ${ }^{18}$. In China, bamboo is widely distributed with an total area of $7.2 \times 10^{6}$ ha, especially in Zhejiang, Fujian and Jiangxi Provinces ${ }^{17}$. Recently, Parr et al. ${ }^{5}$ and Song et al. ${ }^{19}$ estimated the global production of phytolith and PhytOC in bamboo. Furthermore, Song et al. ${ }^{19}$ compared the production of PhytOC in bamboo with other forests in China. However, their studies were only based on a limited number of bamboo species $(<11)$. The phylogenetic variation of phytolith in bamboo leaves has not been investigated. Therefore, this study selected 75 different bamboo species to explore the phylogenetic variation in phytolith composition and phytolith production of bamboo.

\title{
Results
}

The phytolith content in leaves of the 75 bamboo species ranged significantly from $4.28 \%$ to $16.42 \%$, mostly within $8 \%-14 \%$ and with a mean of $9.59 \%$ (Table 1, Fig. 1). The highest phytolith content was in leaves of Pleioblastus kongosanensis, Phyllostachys sulphurea viridisulcata, Phyllostachys ventricosa cv huangganlucao and Phyllostachys ventricosa cv. luganhuangcao, with a mean of higher than $14 \%$. The phytolith content in the leaves of Chimonobambusa quadrangularis, Phyllostachys prominensa and Phyllostachys aureosulcata $f$. aureocaulis was the lowest, with a mean of $4.28 \%, 4.52 \%$ and $4.84 \%$, respectively. There was a significant variation in the phytolith content of bamboo leaves from different genera (Fig. 2A). The phytolith content was the highest in Sasa, while the lowest in Chimonobambusa, Indocalamus and Acidosasa (Table 1; Fig. 2A). There was no obvious variation in leaf phytolith content for bamboos belonging to different subtribes, bambuseaes and bambusataes (Fig. 2B-D). The C content of phytolith for bamboo varies slightly from $2.0 \%$ to $3.2 \%$, with a median of $2.6 \%$ (Fig. 3 ). 


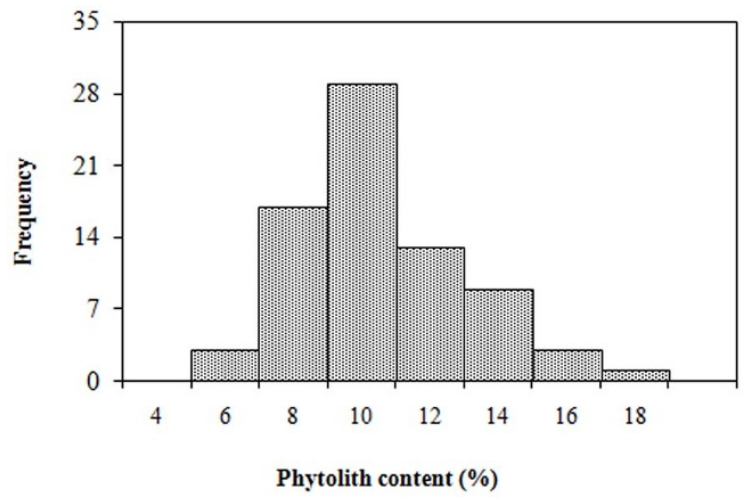

Figure $1 \mid$ Frequency distribution of phytolith content within 75 bamboo species.

\section{Discussion}

Recent studies indicate that the silicon $(\mathrm{Si})$ content is higher in nonvascular plants and horsetails than in ferns, gymnosperms and angiosperms; higher in monocotyledons than in dicotyledons; and higher in gramineous plants and the Palmales than in other orders of plants $^{20,21}$. Furthermore, the phylogenetic variation in Si content in different phyla is greater than that of the lower level classifications such as order and family ${ }^{20,21}$. Some researches show that there is a strong positive correlation between the phytolith and $\mathrm{SiO}_{2}$ contents of biomass ${ }^{5,15,19}$. The above findings may have broad implications for phylogenetic variation in phytolith content of plants.

The dramatic variations of phytolith content within leaves of different bamboo species and genera may be due to different absorption capacities of $\mathrm{Si}^{5,22,23}$. Although the $\mathrm{Si}$ can be taken up by plant roots in the form of $\mathrm{Si}(\mathrm{OH})_{4}$, through the transpiration stream ${ }^{24-26}$, the ability of transpiration for Si may vary in bamboos of different genera or species $^{27}$. So, the deposition of Si among different bamboo also differs significantly. The different origins of bamboo species may also influence the Si deposition within leaves ${ }^{13,28,29}$. For example, the different soil Si supply capacity from their original sites also leads to the different absorption capacity of $\mathrm{Si}$ in plants $^{13,28,29}$. In addition, the hereditary variability of bamboo species could also affect the Si absorption capacity ${ }^{30}$. Although the mechanisms of Si absorption for some plants such as rice $e^{28,29,31}$, wheat ${ }^{32}$ and soybean ${ }^{33}$ have been reported by many researchers, that mechanisms of Si absorption in bamboo and the influence of different levels of phylogenetic classification on bamboo phytolith accumulation remain to be revealed.

Recent researches have shown that PhytOC is much more stable than other organic carbon fractions in soils or some sediments, and can occupy up to $82 \%$ of the total carbon accumulation in a 2000 year old soil profile $\mathrm{e}^{8,13}$ suggesting that PhytOC accumulation has a crucial role in long-term terrestrial carbon sink and global climate change $^{2,3,5,15,34}$.

We have examined the relationship of PhytOC content of bamboo leaf and phytolith content (Fig. 4A) and carbon content of phytolith and phytolith content (Fig. 4B). In contrast with Parr et $\mathrm{al}^{5}{ }^{5}$, the results show that there is no significantly negative relationship ( $p$ $>0.05$ ) between phytolith content and carbon content of phytoliths but significantly positive relationship between the phytolith content and the PhytOC content in bamboo leaves. The results imply that increasing phytolith content is a potential measure to increase phytolith $\mathrm{C}$ accumulation.

Taking the $\mathrm{C}$ content in phytoliths of $3 \pm 1 \%$ (Fig. 3; ref. 5 and 19) and net primary production for bamboo leaf litters of $5955 \pm$ $1000 \mathrm{~kg} \mathrm{ha}^{-1} \mathrm{yr}^{-119,35}$, we estimate that the phytolith carbon sequestration flux of bamboo is 28.04-107.55 $\mathrm{kg} \mathrm{CO}_{2} \mathrm{ha}^{-1} \mathrm{yr}^{-1}$, with an average of $62.83 \mathrm{~kg} \mathrm{CO}_{2} \mathrm{ha}^{-1} \mathrm{yr}^{-1}$. Taking China's current bamboo area of $7.2 \times 10^{6}$ ha and the mean bamboo PhytOC production flux of $62.83 \mathrm{~kg} \mathrm{CO}_{2} \mathrm{ha}^{-1} \mathrm{yr}^{-1}$, we estimate that about $4.52 \times 10^{8} \mathrm{~kg} \mathrm{CO}_{2}$
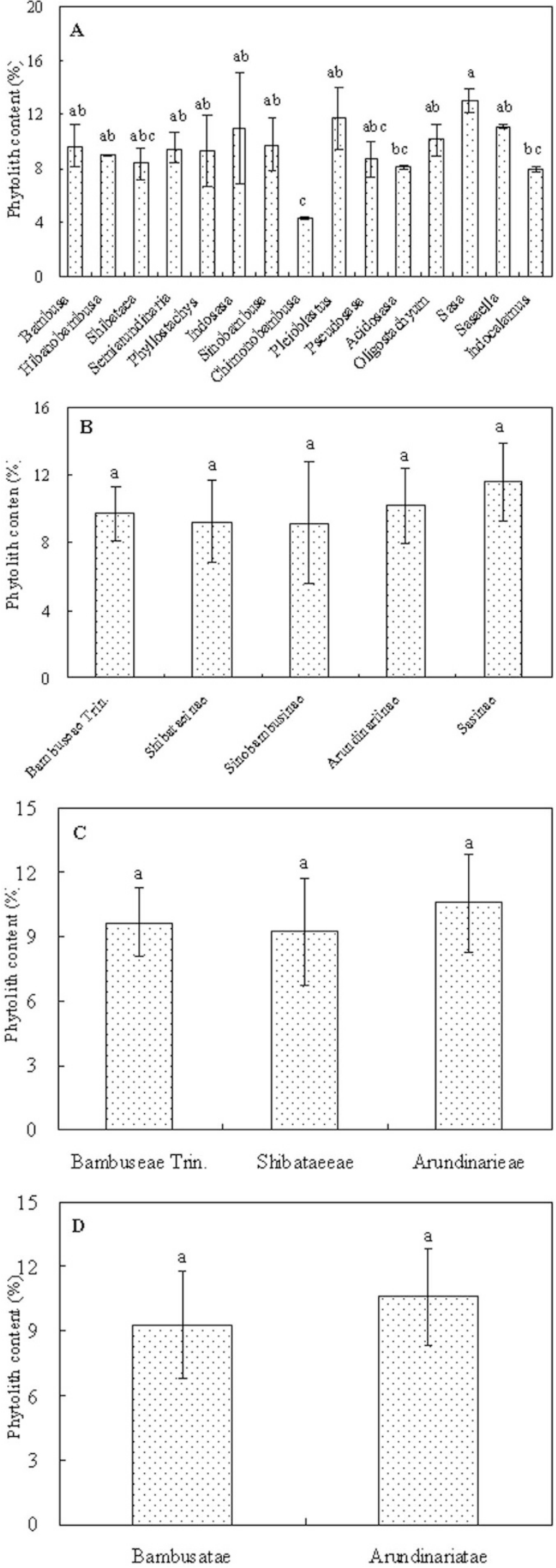

Figure $2 \mid$ Phytolith content in leaves for bamboo of: (A) different genera, (B) different subtribes, (C) different bambuseaes, (D) different bambusataes. Different letters above the error bars indicate significant difference among the different bamboo at $p<0.05$ levels. 


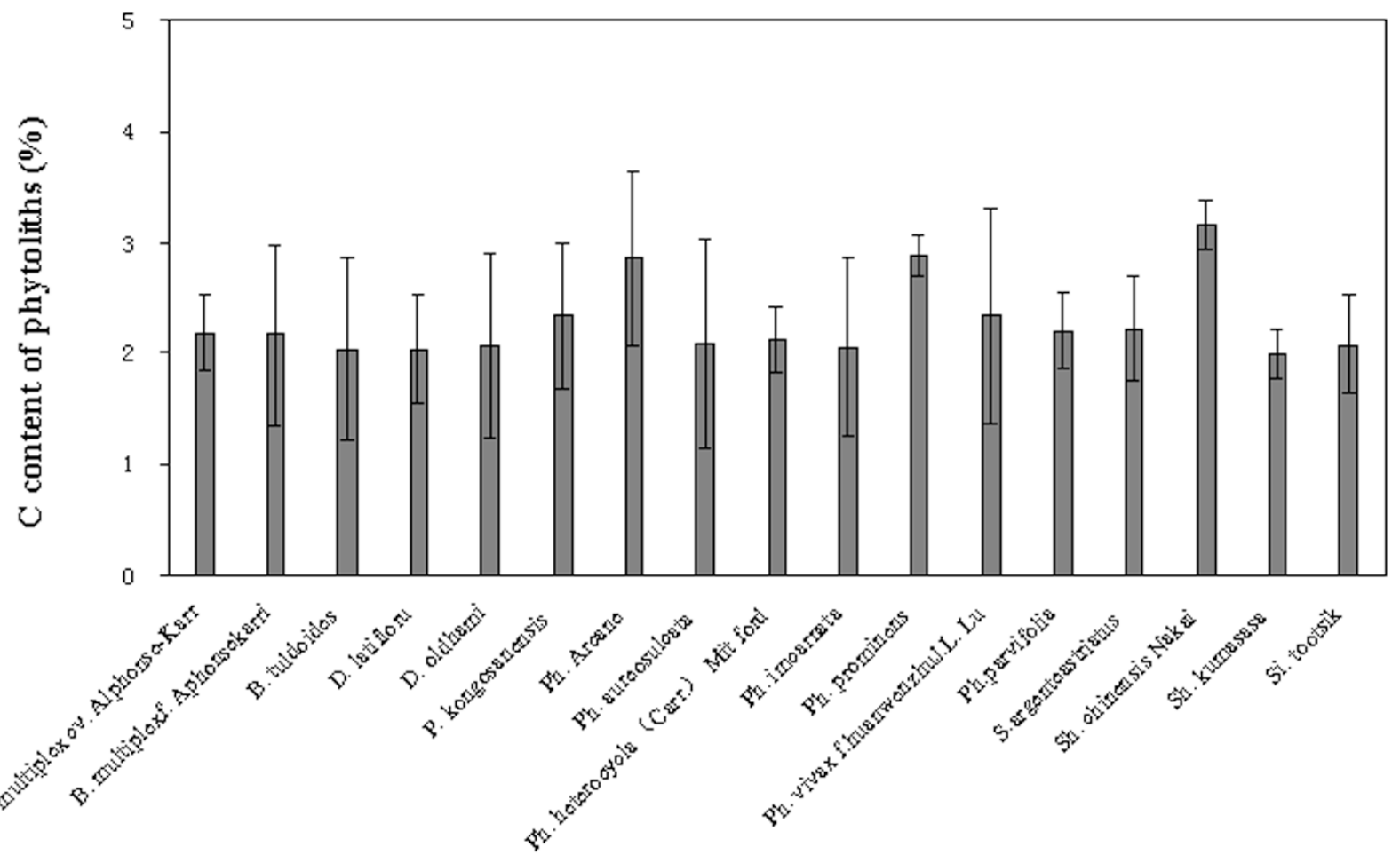

Figure 3 The variation of the occluded C content of phytoliths in bamboo leaves. Different letters above the error bars indicate significant difference among bamboo bambuseaes at $p<0.05$ levels.

$\mathrm{yr}^{-1}$ would be sequestered in phytoliths of Chinese bamboo forests. As shown in Table 1, it is possible to improve the production flux of PhytOC by selecting bamboo species (e.g., Pleioblastus kongosanensis, Phyllostachys sulphurea viridisulcata) with high phytolith content $\mathrm{t}^{5,15}$. If those bamboo species could be widely planted in China, 7.2 $\times 10^{8} \mathrm{~kg} \mathrm{CO}$ from the atmosphere would be captured within bamboo phytoliths.

The global bamboo distribution area is $2.2 \times 10^{7}$ ha, occupying about $1 \%$ of the global forests ${ }^{17,18}$, and is mainly distributed in tropical and subtropical regions such as China, India, Thailand and $\operatorname{Japan}^{17,18,36}$. Taking the mean PhytOC production flux of $62.83 \mathrm{~kg}$ $\mathrm{CO}_{2} \mathrm{ha}^{-1} \mathrm{y}^{-1}$, we estimate that approximately $1.4 \times 10^{9} \mathrm{~kg} \mathrm{CO}$ would be sequestered in bamboo phytoliths globally each year. However, if the highest PhytOC production flux of $107.55 \mathrm{~kg} \mathrm{CO}$ $\mathrm{ha}^{-1} \mathrm{y}^{-1}$ can be reached, atmospheric sequestration of $2.4 \times 10^{9} \mathrm{~kg}$ $\mathrm{CO}_{2}$ each year through global bamboo phytolith is possible. Assuming an increase rate of bamboo area of $3 \%$ annually ${ }^{37,38}$ and the mean PhytOC production flux in bamboo of $62.83 \mathrm{~kg} \mathrm{CO}_{2} \mathrm{ha}^{-1}$ $\mathrm{y}^{-1}$, then at least $2.8 \times 10^{9} \mathrm{~kg} \mathrm{CO}_{2}$ from the atmosphere would be sequestered in bamboo phytoliths globally by 2050 . Taking the highest PhytOC production flux, $4.7 \times 10^{9} \mathrm{~kg} \mathrm{CO}_{2}$ would be sequestered in bamboo phytoliths globally.

Although the total forest area of the world has decreased significantly, the total area of bamboo forests has increased at a rate of 3\% annually and will continue to increase in the next decades ${ }^{19}$. For example, it was estimated that an area of $27 \times 10^{7}$ ha may be available for afforestation in China and at least half of the land can be used for bamboo afforestation ${ }^{18,19}$. Furthermore, the world's bamboo may increase from $25 \times 10^{6}$ to $100 \times 10^{6}$ ha (approximately $3 \%$ of world's forests) by taking measures of bamboo afforestation/reforestation in the tropical and subtropical area of the world ${ }^{18,19}$. Therefore, it is possible to significantly increase phytolith carbon sink in bamboo forests by both increasing the bamboo area and selecting high phytolith-content bamboo species such as Pleioblastus kongosanensis, Ph. Ventricosa cv. Luganhuangcao and Phyllostachys Ventricosa cv Huangganlucao.

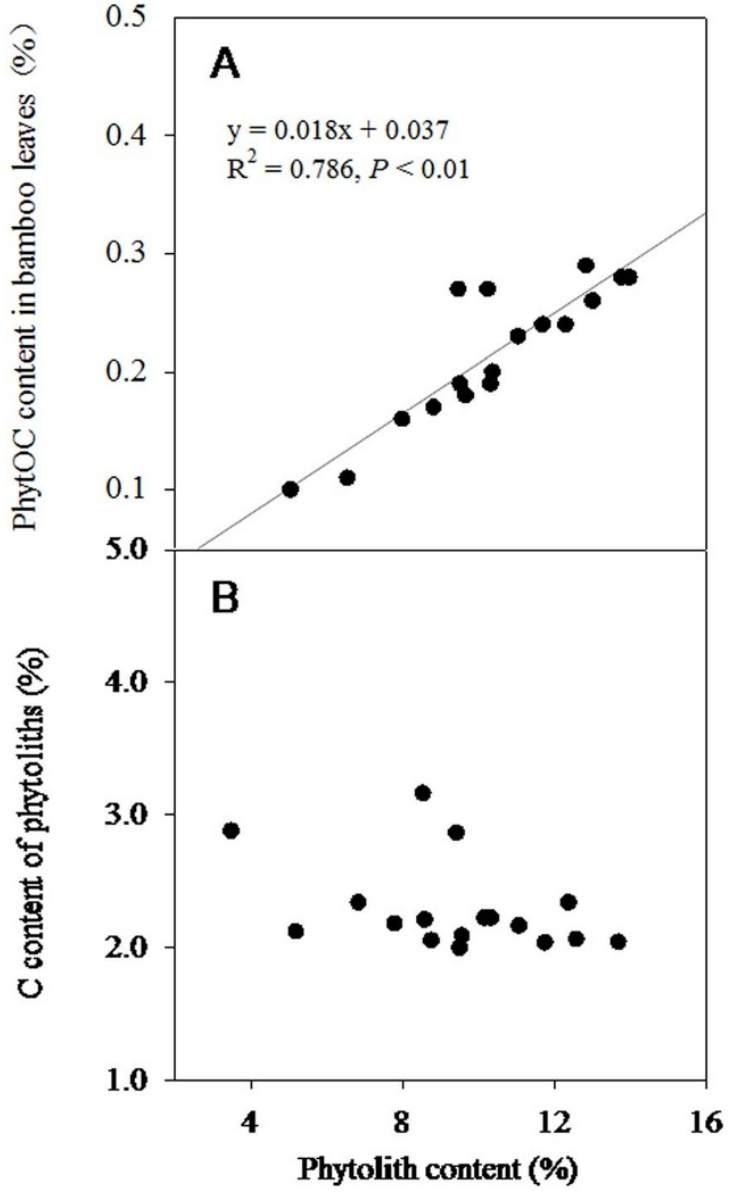

Figure $4 \mid$ The relationship between the phytolith content and the carbon content of phytoliths $(p>0.05)(A)$, and between the phytolith content and the PhytOC content in bamboo leaves (B). 
Table 1 | Phylogenetic variation of phytolith content in bamboo leaves

\begin{tabular}{|c|c|c|c|c|c|}
\hline Bambusatae & Bambuseae & Subtribe & Genus & Species & Phytolith (\%) ${ }^{a}$ \\
\hline Bambusatae & Bambuseae Trin. & Sinobambusinae & $\begin{array}{l}\text { Hibanobambusa } \\
\text { Shibataea } \\
\text { Semiarundinaria } \\
\text { Phyllostachys }\end{array}$ & $\begin{array}{l}\text { B.rutila } \\
\text { B. multiplex } \\
\text { B. multiplex cv. Changye } \\
\text { B.multiplex raeuschel } \\
\text { B.alphonsekarri } \\
\text { B.glaucescens } \\
\text { H.tranguillans.shiroshima } \\
\text { Sh.kumasasa } \\
\text { Sh. chinensis nakai } \\
\text { Sh. chinensis nakai cv. jimao } \\
\text { S. yashadake f. kimmei } \\
\text { S. yashadake makino } \\
\text { S. yashadake f. ogon } \\
\text { Ph.prominens } \\
\text { Ph.vivax. huanwenzhu } \\
\text { Ph.heterocycla taokiang } \\
\text { Ph.heterocycla } \\
\text { Ph.incarnata } \\
\text { Ph. bambusoides } \\
\text { Ph. bambusoides. cv. huayehuagan } \\
\text { Ph.bambusoides.castillonis } \\
\text { Ph. nigra } \\
\text { Ph. nigra. cv. huaye } \\
\text { Ph.aureosulcata.pekinensis } \\
\text { Ph.aureosulcata } \\
\text { Ph.aureosulcata.aureocaulis } \\
\text { Ph.aureosulcata.spectabilis } \\
\text { Ph.sulphurea.viridis } \\
\text { Ph.sulphurea viridisulcata } \\
\text { Ph. sulphurea } \\
\text { Ph. houzeavana } \\
\text { Ph. ventricosa } \\
\text { Ph. ventricosa cv huangganlucao } \\
\text { Ph. ventricosa cv. luganhuangcao } \\
\text { Ph. ventricosa cv. huangiin } \\
\text { Ph.arcana.luteosulcata } \\
\text { Ph.propinqua } \\
\text { Ph.vivax.aureocaulis } \\
\text { Ph. heterocycla.gracilis } \\
\text { Ph.nigra.henonis } \\
\text { Ph.dulcis } \\
\text { Ph.parvifolia } \\
\text { Ph. violascens cv. xiye } \\
\text { Ph. violascens cv. jianye } \\
\text { Ph. violascens cv. viridisulcata } \\
\text { Ph. violascens cv. flavistriatus } \\
\text { Ph. violascens cv. panggan } \\
\text { Ph. violascens cv. anhuiensis } \\
\text { Ph. violascens cv. flavivaginis } \\
\text { Ph. violascens cv. violascens } \\
\text { Ph.bambussoides } \\
\text { Ph.aureosulcata } \\
\text { Ph. violascens cv. linanesis } \\
\text { l.acutiligulata } \\
\text { I.sinica } \\
\text { S. tootsik } \\
\text { S. tootsik.cv. huaye } \\
\text { Ch.quadrangularis }\end{array}$ & $\begin{array}{r}10.41 \\
11.92 \\
10.02 \\
8.17 \\
10.12 \\
7.43 \\
9.01 \\
9.74 \\
7.89 \\
7.52 \\
8.99 \\
8.64 \\
10.83 \\
4.52 \\
6.59 \\
7.50 \\
6.82 \\
7.82 \\
9.84 \\
11.24 \\
8.96 \\
9.43 \\
9.87 \\
7.18 \\
7.68 \\
4.84 \\
8.30 \\
13.99 \\
15.63 \\
12.07 \\
8.99 \\
9.87 \\
16.42 \\
14.83 \\
9.08 \\
9.10 .38 \\
8.05 \\
13.92 \\
4.15 \\
9.40 \\
7.56 \\
8.09 \\
8.59 \\
10.02 \\
7.78 \\
9.48 \\
9.81 \\
12.41 \\
10.50 \\
10.32 \\
7.81 \\
7.52 \\
7.32 \\
8.50 \\
\end{array}$ \\
\hline
\end{tabular}


Table 1 | Continued

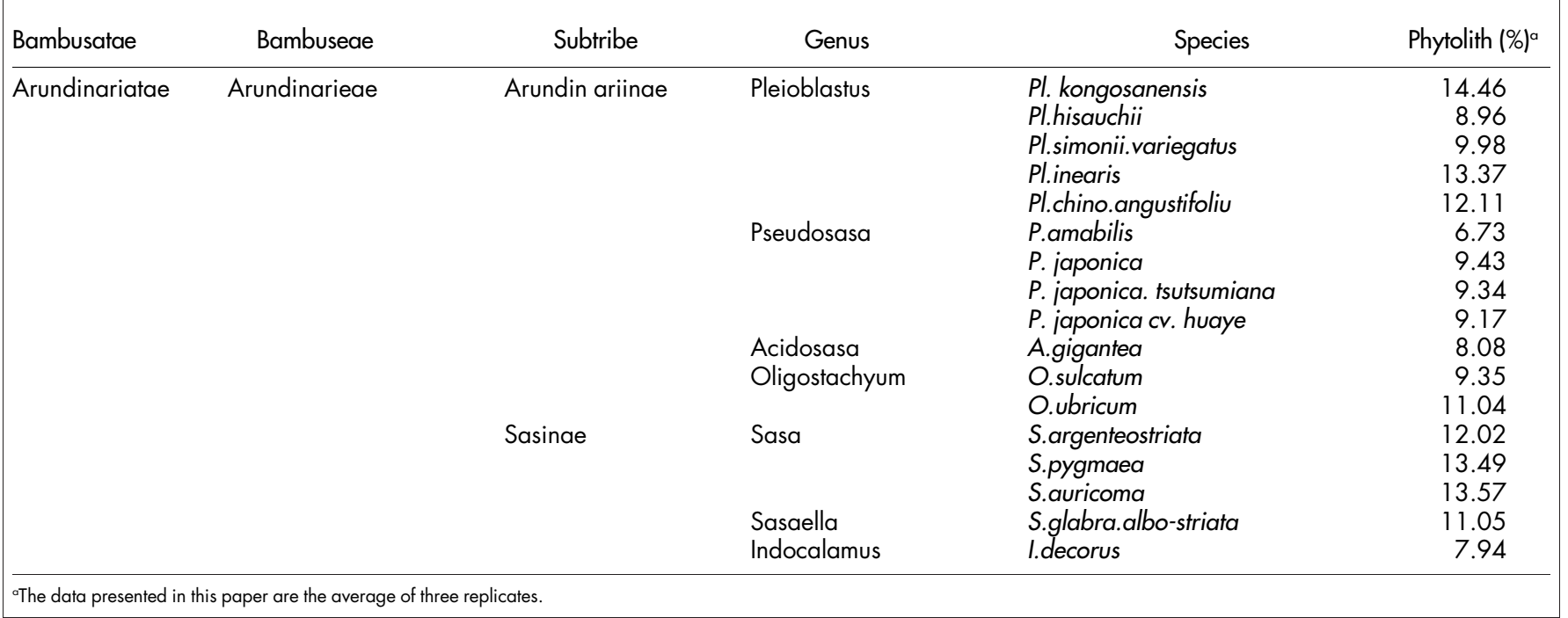

\section{Methods}

Experimental site. Fresh mature (two-year old) leaf samples were collected from 75 different bamboo species belonging to two bambusataes, three bambuseaes, five subtribes and 15 genera in the botanical garden at Zhejiang Agricultural and Forestry University $\left(30^{\circ} 15^{\prime} \mathrm{N}, 119^{\circ} 43^{\prime} \mathrm{E}\right)$, Lin'an, Zhejiang, China. Lin'an is located in western Zhejiang and has a subtropical monsoon climate with an average elevation of $150 \mathrm{~m}$ above sea level. The distribution of precipitation is uneven, with an average of $1400 \mathrm{~mm} \mathrm{y}^{-1}$. The annual frost-free period is up to $234 \mathrm{~d}$, and the annual average temperature is $16^{\circ} \mathrm{C}$.

Experimental design and Analyses of the phytolith in samples. The leaves of the different bamboo species were used to examine the variability of phytolith production. Mature leaf samples were collected in May 2012, when they have higher phytolith content than that in younger leaves ${ }^{5,39}$. Each leaf sample was mixed, rinsed with ultrapure water, oven-dried at $75^{\circ} \mathrm{C}$ for $48 \mathrm{~h}$ to a constant mass and then cut into small pieces $(<5 \mathrm{~mm})$ for phytolith analysis. The phytoliths within bamboo leaves were extracted with a microwave digestion process ${ }^{40}$ and Walkley-Black type digest ${ }^{41}$. The extracted phytoliths were oven-dried at $75^{\circ} \mathrm{C}$ to a constant weight. Dried phytoliths were weighed and recorded for phytolith content calculation. Occluded C content of phytoliths was determined with methods of ref. 15.

Data calculations and statistics. The data presented in this paper were the average of three replicates. Excel and SPSS were employed in the statistical analysis of data. Oneway ANOVA and Duncan's Multiple Range Test $(p<0.05)$ were applied to examine the difference of data groups.

1. Piperno, D. Phytoliths. Tracking environmental change using lake sediments 235-251 (2002).

2. Song, Z. L., Liu, H. Y., Si, Y. \& Yin, Y. The production of phytoliths in China's grasslands: implications to the biogeochemical sequestration of atmospheric $\mathrm{CO}_{2}$. Global Change Biol. 18, 3647-3653 (2012a).

3. Song, Z. L., Wang, H. L., Strong, P. J., Li, Z. M. \& Jiang, P. K. Plant impact on the coupled terrestrial biogeochemical cycles of silicon and carbon: Implications for biogeochemical carbon sequestration. Earth-Sci. Rev. 115, 319-331 (2012b).

4. Perry, C. C., Williams, R. J. P. \& Fry, S. C. Cell wall biosynthesis during silicification of grass hairs. J. Plant Physiol. 126, 437-448 (1987).

5. Parr, J. F., Sullivan, L. A., Chen, B., Ye, G. \& Zheng, W. Carbon bio-sequestration within the phytoliths of economic bamboo species. Global Change Biol. 16, 2661-2667 (2010).

6. Alexandre, A., Meunier, J. D., Colin, F. \& Koud, J. M. Plant impact on the biogeochemical cycle of silicon and related weathering processes. Geochim. Cosmochim. Acta 61, 677-682 (1997).

7. Wilding, L. P. Radiocarbon dating of biogenetic opal. Science 156, 66-67 (1967).

8. Parr, J. F. \& Sullivan, L. A. Soil carbon sequestration in phytoliths. Soil Biol. Biochem. 37, 117-124 (2005).

9. Baker, G. Opal phytoliths and adventitious mineral particles in wheat dust. Mineral Investigations Technical Paper No. Melbourne, Australia 4 (1961).

10. Baker, G., Jones, L. H. P. \& Wardrop, I. D. Opal phytoliths and mineral particles in the rumen of the sheep. Crop Pasture Sci. 12, 462-472 (1961).

11. Wilding, L. P., Brown, R. E. \& Holowaychuk, N. Accessibility and properties of occluded carbon in biogenetic opal. Soil Sci. 103, 56-61 (1967).
12. Mulholland, S. C. \& Prior, C. AMS radiocarbon dating of phytoliths. MASCA research papers in science and archaeology 10, 21-23 (1993).

13. Parr, J. F. \& Sullivan, L. A. Phytolith occluded carbon and silica variability in wheat cultivars. Plant Soil 342, 165-171 (2011).

14. Gifford, R. M. The global carbon cycle: a viewpoint on the missing sink. Funct. Plant Biol. 21, 1-15 (1994).

15. Li, Z. M., Song, Z. L., Parr, J. F. \& Wang, H. L. Occluded C in rice phytoliths: implications to biogeochemical carbon sequestration. Plant Soil 370, 615-623 (2013).

16. Li, Z., Lin, P., He, J., Yang, Z. \& Lin, Y. Silicon's organic pool and biological cycle in moso bamboo community of Wuyishan Biosphere. J. Zhejiang Univ. Sci. B 7, 849-857 (2006).

17. Cao, Z. H., Zhou, G. M. \& Wong, M. H. Bamboo and Climate Change in China. Bot. Rev. 77, 188-189 (2011).

18. Zhou, G. M., Meng, C. F., Jiang, P. \& Xu, Q. F. Review of carbon fixation in bamboo forests in China. Bot. Rev. 77, 262-270 (2011).

19. Song, Z. L., Liu, H. Y., Li, B. L. \& Yang, X. M. The production of phytolithoccluded carbon in China's forests: implications to biogeochemical carbon sequestration. Global Change Biol. 19, 2907-2915 (2013).

20. Carnelli, A. L., Madella, M. \& Theurillat, J. P. Biogenic silica production in selected alpine plant species and plant communities. Ann. Bot. 87, 425-434 (2001).

21. Hodson, M. J., White, P. J., Mead, A. \& Broadley, M. R. Phylogenetic variation in the silicon composition of plants. Ann. Bot. 96, 1027-1046 (2005).

22. Takahashi, E., Ma, J. F. \& Miyake, Y. The possibility of silicon as an essential element for higher plants. Comment Agr. Food. Chem. 2, 99-102 (1990).

23. Ding, T. P. et al. Silicon isotope fractionation in bamboo and its significance to the biogeochemical cycle of silicon. Geochim. Cosmochim. Acta 72, 1381-1395 (2008).

24. Gong, H. J., Chen, K. M., Wang, S. M. \& Zhang, C. L. Advances in silicon nutrition of plants. Acta Bot. Boreali-Occidentalia Sin. 24, 2385-2392 (2004).

25. Siever, R. \& Scott, R. A. Organic geochemistry of silica. Organic geochemistry. Pergamin, New York, 579-595 (1963).

26. Ranganathan, S. et al. Effects of silicon sources on its deposition, chlorophyll content, and disease and pest resistance in rice. Biologia Plantarum 50, 713-716 (2006).

27. Leng, M. J. et al. The potential use of silicon isotope composition of biogenic silica as a proxy for environmental change. Silicon 1, 65-77 (2009).

28. Ma, J. F. et al. A silicon transporter in rice. Nature 440, 688-691 (2006).

29. Ma, J. F. et al. An efflux transporter of silicon in rice. Nature 448, 209-212 (2007).

30. Collin, B., Doelsch, E., Keller, C., Panfili, F. \& Meunier, J. D. Distribution and variability of silicon, copper and zinc in different bamboo species. Plant soil 351, 377-387 (2012).

31. Chen, W., Yao, X., Cai, K. Z. \& Chen, J. N. Silicon alleviates drought stress of rice plants by improving plant water status, photosynthesis and mineral nutrient absorption. Biol. Trace Element Res. 142, 67-76 (2011).

32. Liang, Y. C., Sun, W. C., Zhu, Y. G. \& Christie, P. Mechanisms of silicon-mediated alleviation of abiotic stresses in higher plants: a review. Environ. Pollut 147, 422-428 (2007).

33. Shen, X. F., Li, Z. H., Duan, L. S. \& Li, J. M. Effect of silicon on carbon metabolism and yield of soybean. Soybean Sci. (In Chinese with English abstract) 32, 193-196 (2013).

34. Zuo, X. X. \& Lü, H. Y. Carbon sequestration within millet phytoliths from dryfarming of crops in China. Chinese Sci. Bull. 56, 3451-3456 (2011). 
35. Yu, Y. et al. The structure and aboveground biomass of Pleioblastus amarus population in Changning. J. Sichuan Forest Sci Tech. (In Chinese with English abstract) 26, 90-93 (2005)

36. Song, Z. L. et al. Plant impact on $\mathrm{CO}_{2}$ consumption by silicate weathering: the role of bamboo. Bot. Rev. 77, 208-213 (2011).

37. Guo, Q. R., Yang, G. Y., Du, T. Z. \& Shi, J. M. Carbon character of Chinese bamboo forest. World Bamboo Rattan 3, 25-28 (2005).

38. Chen, X. G., Zhang, X. Q., Zhang, Y. P., Booth, T. \& He, X. H. Changes of carbon stocks in bamboo stands in China during 100 years. Forest Ecol. Manag. 258, 1489-1496 (2009).

39. Motomura, H., Mita, N. \& Suzuki, M. Silica accumulation in long-lived leaves of Sasa veitchii (Carrière) Rehder (Poaceae-Bambusoideae). Ann. Bot. 90, 149-152 (2002)

40. Parr, J. F., Dolic, V., Lancaster, G. \& Boyd, W. E. A microwave digestion method for the extraction of phytoliths from herbarium specimens. Rev. Palaeobot. Palyno. 116, 203-212 (2001).

41. Walkley, A. \& Black, I. A. An examination of the Degtjareff method for determining soil organic matter, and a proposed modification of the chromic acid titration method. Soil Sci. 37, 29-38 (1934).

\section{Acknowledgments}

We are grateful for support from National Natural Science Foundation of China (Grant No. 41103042), Training Program for the Top Young Talents of Zhejiang Agricultural and
Forestry University, Frontier Project of Institute of Geochemistry, Chinese Academy of Sciences, Opening Fund of Tianjin Key Laboratory of Water Resources and Environment (52XS1202).

\section{Author contributions}

B.L., R.G., R.S. and Z.S. carried out the sampling. B.L. and Z.L. performed the experimental work. B.L., H.W. and Z.S. analyzed the data. Z.S. designed the study and supervised the project. All authors discussed the results and contributed to the manuscript.

\section{Additional information}

Competing financial interests: The authors declare no competing financial interests.

How to cite this article: Li, B.L. et al. Phylogenetic variation of phytolith carbon sequestration in bamboos. Sci. Rep. 4, 4710; DOI:10.1038/srep04710 (2014).

This work is licensed under a Creative Commons Attribution-NonCommercialNoDerivs 3.0 Unported License. The images in this article are included in the article's Creative Commons license, unless indicated otherwise in the image credit; if the image is not included under the Creative Commons license, users will need to obtain permission from the license holder in order to reproduce the image. To view a copy of this license, visit http://creativecommons.org/licenses/by-nc-nd/3.0/ 